\title{
Signet-ring cell carcinoma of the nonampullary duodenum and proximal jejunum: a case report with an immunohistochemical study
}

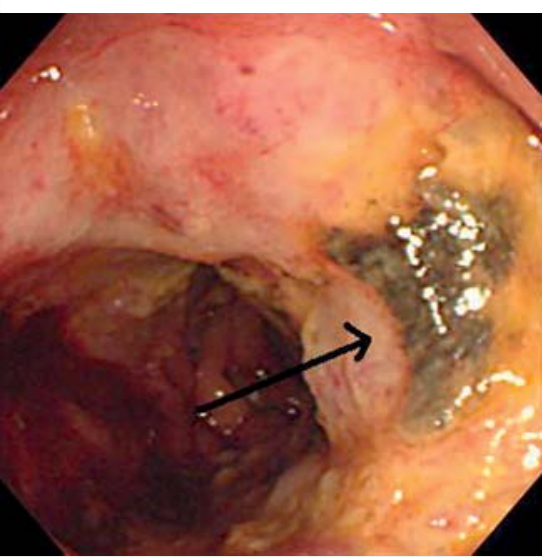

Fig. 1 Endoscopy shows an ulcerated tumor (arrow) of the third portion of the duodenum.

Fewer than 20 cases of signet-ring cell carcinoma (SRCC) of the ampulla of Vater have been reported [1-4]. There have been no reports to date of SRCC of the nonampullary duodenum and ileum.

A 71-year-old man presented with nausea. Upper gastrointestinal endoscopy showed two ulcerated tumors ( $\bullet$ Fig. 1 ) of the third portion of the duodenum and in the proximal jejunum. Biopsies were taken. The stomach was free from tumor. CT demonstrated brain metastases. The patient was treated by chemoradiotherapy, but died of carcinomatosis 4 months after initial presentation.

Histologic examination of the biopsies of both tumors showed apparent SRCC
( Fig. 2). Approximately $80 \%$ of the tumor was composed of SRCC cells. Histochemically, the SRCC cells were positive for mucins. Immunohistochemically [5], the SRCC cells were positive for cytokeratin AE1/3, cytokeratin CAM5.2, CK34BE12, cytokeratin 7 (CK7), cytokeratin 8 (CK8), cytokeratin 18 (CK18), cytokeratin 19 (CK19), epithelial membrane antigen (EMA), p53, Ki-67 (labeling=70\%), mucin 1 (MUC1), and mucin 6 (MUC6). They were negative for cytokeratin 5/6 (CK5/6), cytokeratin 14 (CK14), cytokeratin 20 (CK20), carcinoembryonic antigen (CEA), carbohydrate antigen 19-9 (CA19-9), vimentin, p63, thyroid transcription factor 1 (TTF-1), homeobox protein CDX-2 (CDX2), mucin 2 (MUC2), and mucin 5AC (MUC5AC).

The present case is the first reported one of SRCC of the nonampullary duodenum and proximal duodenum. Although the primary site is unclear, the present author thinks that the duodenal tumor was primary and the jejunal tumor was a metastasis. The cytokeratin profile was compatible with pancreatobiliary cytokeratins, which are CK7, CK8, CK18, and CK19 [6]. However, the MUC apomucin profile was not of the pancreatobiliary type [6]. The positive CK34BE12 staining suggests that this high-molecular cytokeratin emerged during carcinogenesis. CK5/6, CK14, and CK20 are known to be absent in the duodenal epithelium. The positive p53 stain-

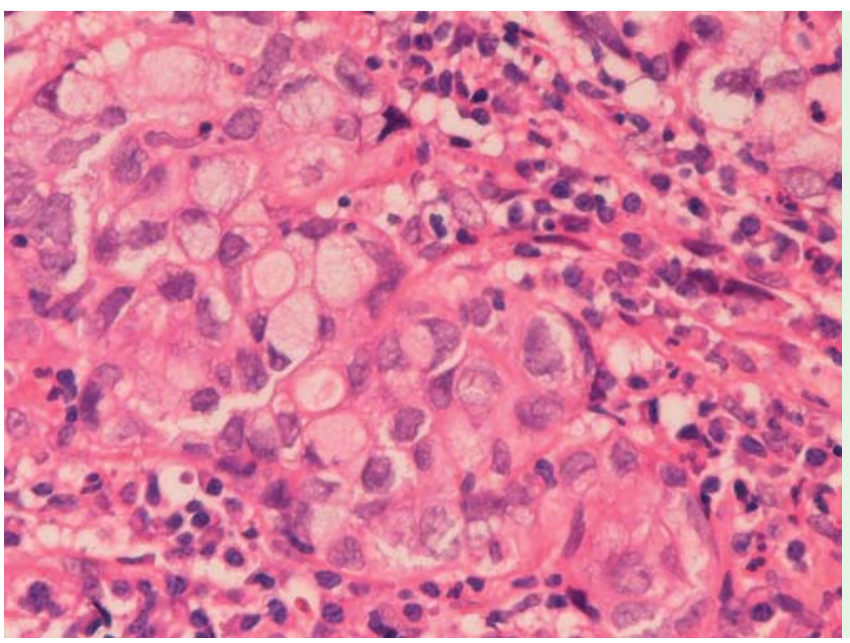

Fig. 2 Histologic section of biopsy specimen. Signet-ring cell carcinoma is apparent $(H \& E, \times 200)$ ing in the present case suggests p53 mutations. The high Ki-67 labeling indicates a high proliferative fraction. The EMA is known to be positive in duodenal epithelium. The negative immunoreactivities of CEA and CA19-9 indicate that this SRCC does produce these cancer-related antigens. TTF-1 and CDX2 indicate that the present tumor is not associated with lung and colon phenotypes.

Endoscopy_UCTN_Code_CCL_1AB_2AZ_3AB

\section{Competing interests: None}

\section{T. Terada}

Department of Pathology, Shizuoka City Shimizu Hospital, Shizuoka, Japan

\section{References}

1 Gardner HA, Matthews J, Ciano PS. A signetring cell carcinoma of the ampulla of Vater. Arch Pathol Lab Med 1990; 114: 1071 1072

2 Paplomata E, Wilfong $L$. Signet ring cell carcinoma of the ampulla of Vater with leptomeningeal metastases: a case report. J Clin Oncol 2011: 29 e627-629

3 Gheza F, Cervi E, Pulcini G et al. Signet ring cell carcinoma of the ampulla of Vater: demonstration of pancreaticobiliary origin. Pancreas 2011; 40: 791-793

4 Tas A, Ozer E, Koklu $S$ et al. Signet ring cell carcinoma of the ampulla of Vater: a rare case of acute pancreatitis. Scand J Gastroenterol 2011; 46: 126-127

5 Terada T, Kawaguchi M, Furukawa $K$ et al. Minute mixed ductal-endocrine carcinoma of the pancreas with predominant intraductal growth. Pathol Int 2002; 52: 740 - 746

6 Hruban RH, Kloppel G, Boffetta P et al. Ductal adenocarcinoma of the pancreas. In: Bosman FT, Carneiro F, Hruban RH, Theise ND, eds. WHO classification of tumours of the digestive system. Lyon: IARC; 2010: 281 291

\section{Bibliography}

DOI http://dx.doi.org/

10.1055/s-0031-1291528

Endoscopy 2014; 46: E348

(c) Georg Thieme Verlag KC Stuttgart · New York

ISSN 0013-726X

\author{
Corresponding author \\ T. Terada, MD, PhD \\ Department of Pathology \\ Shizuoka City Shimizu Hospital \\ Miyakami 1231 Shimizu-Ku \\ Shizuoka 424-8636 \\ Japan \\ Fax: +81-54-3341173 \\ piyo0111jp@yahoo.co.jp
}

